\title{
PROCESS INTEGRATION INVOLVING LIPASE-CATALYZED ESTER SYNTHESIS REACTIONS
}

\author{
Ana L. Paiva and F. Xavier Malcata* \\ Escola Superior de Biotecnologia, Universidade Católica Portuguesa \\ Rua Dr. António Bernardino de Almeida, 4200 Porto, Portugal
}

\begin{abstract}
Summary
The technical feasibility of integrating bioconversion (using a lipase from Mucor miehei immobilized by ion exchange onto a macroporous resin) and product recovery (via mass transfer towards liquid/vapor equilibrium) was experimentally verified for the production of ethyl acetate from acetic acid and ethanol at 30 and $40^{\circ} \mathrm{C}$. The configuration selected consisted of a packed bed thermostatted reactor inserted between the condenser and the liquid reflux to a distillation column. The concentrations of the aforementioned components and water were measured periodically for a 9 to 10-h period. The extents of conversion of acetic acid ranged from 1 to $32 \%$ at $30^{\circ} \mathrm{C}$, and from 13 to $25 \%$ at $40^{\circ} \mathrm{C}$, and they were maximum at initial molar fractions of acid of ca. 0.3 and 0.4 , respectively. The ratio of the reaction product to the equilibrium reaction product increased from 2 to 32 at $30^{\circ} \mathrm{C}$, and from 5 to 27 at $40^{\circ} \mathrm{C}$ when the initial molar fraction of acid in the feed increased from 0.2 to 0.7 .
\end{abstract}

\section{Introduction}

Most short chain esters are still produced on the industrial level via acid- or base-catalyzed condensation of the corresponding alcohol and carboxylic acid in the presence of transition metals at high temperatures and pressures. However, in addition to the lack of selectivity of the catalyst (which leads to the occurrence of side reactions which yield by-products responsible for off-flavors and off-colors), such extreme conditions often lead to thermal degradation of the products and accelerated corrosion of the reactor matcrial. Lipases are enzymes which, similarly to esterases, are able to catalyze the hydrolysis of ester bonds (albeit with full catalytic activity only at interfaces), as well as its reverse reaction (ester synthesis) at much milder processing conditions, and are thus much more economical in terms of energy requirements. Several examples of ester synthesis reactions involving short-chain carboxylic acids and alcohols catalyzed by immobilized lipases are available in the literature (Norin et al., 1988; Chulalaksananukul et al., 1990; Khurana and Ho, 1990; Knez et al., 1990; Langrand et al., 1990; Welsh et al., 1990; Manjón et al., 1991; Dias et al., 1991).

The purpose of this study was to carry out the synthesis of ethyl acetate from ethanol and acetic acid using a commercially available lipase from $M$ ucor miehei adsorbed by ion exchange onto a macroporous resin (Lipozyme ${ }^{\mathrm{TM}}$ ). To integrate the processes of reaction and separation, the liquid outlet stream from the condenser was fed to the reactor, and the outlet stream from the reactor played the role of the liquid reflux to the distillation column. In this way, thermal degradation of the enzyme was kept to a minimum (due to the relatively low operating temperatures at this location and the fractional removal of water from the reaction medium by distillation), the enzyme concentration was large at all times (due to confinement by 
immobilization in the packed bed reactor), and the rates of reaction were maintained high (due to the reduction of the competitive inhibition by the acid, which was also fractionally removed from the reaction system by distillation). In order to obtain the maximum efficiency for the configuration under scrutiny, the distillation column was operated under total reflux conditions.

\section{Materials and methods}

The experimental set-up, consisting of a batch still, a distillation column, and a packed bed reactor, is depicted in Figure 1.

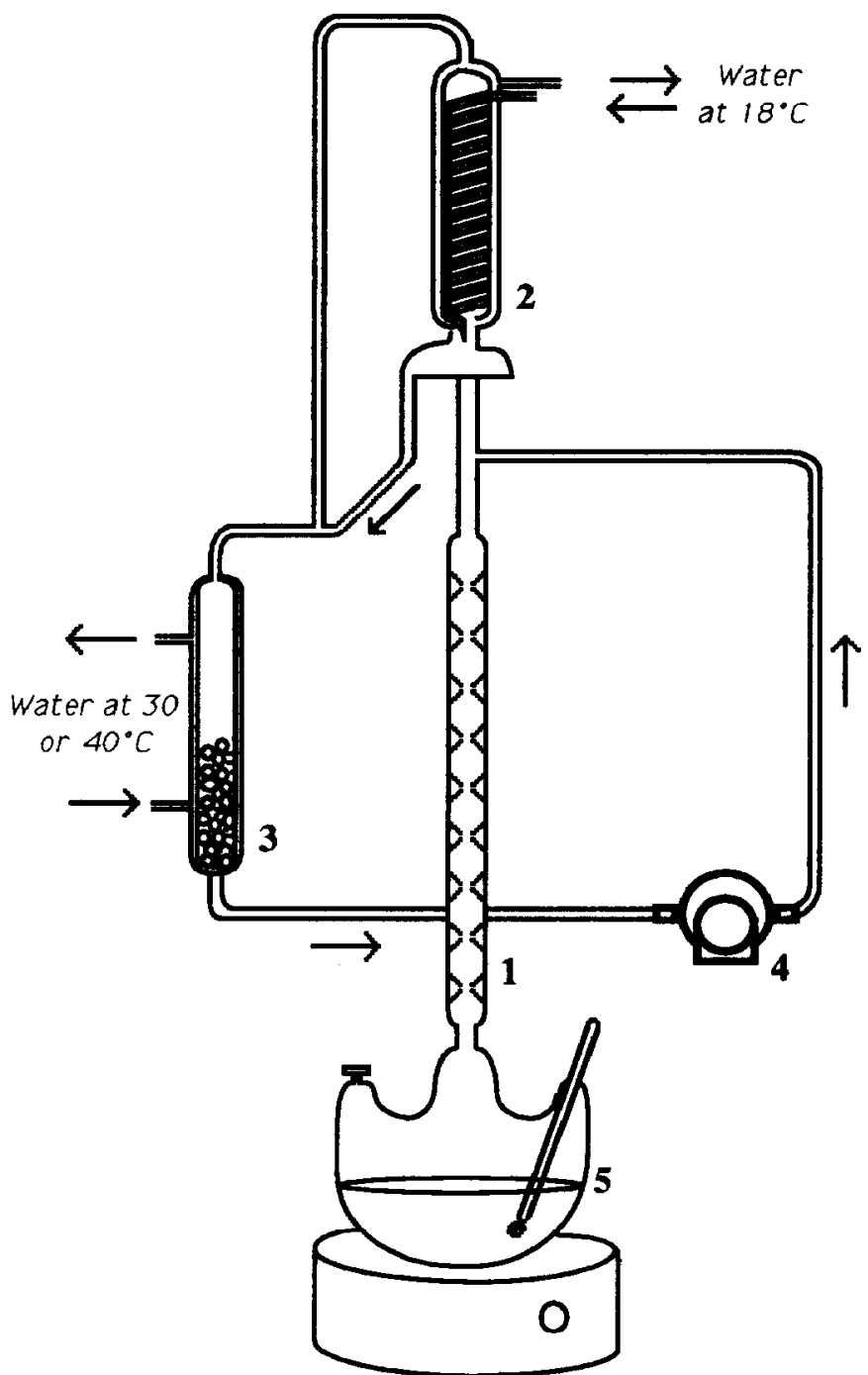

Figure 1: Experimental set-up utilized for the performance of the integrated processes of reaction and separation. 1: distillation column; 2: total condenser; 3: jacketed packed bed reactor; 4: gear pump; 5: batch still.

The still consists of a three-necked 1-L vessel with a thermometer inserted in one of the side necks. The initial mixture was inserted into the still through other of the necks, which was also used to withdraw samples during operation. The third neck was utilized for the connection to the distillation column. The still was heated using an electric heater. The distillation column is a Vigreaux glass column with 8 sets of inner indentations (four horizontal and four pointing upward at a $45^{\circ}$ angle), with a total length of $41 \mathrm{~cm}$ and an internal diameter of $3 \mathrm{~cm}$. In order to keep heat losses to a minimum, the column was externally insulated with a thin layer of 
glass fibre covered with a second thin layer of polyurethane. A shell-and-tube total condenser was fitted to the top of the distillation column; water from an outside thermostatted bath kept at $18^{\circ} \mathrm{C}$ was continuously available for cooling. The liquid reflux from this device was conducted to the reactor, which consists of a vertically positioned jacketed column containing, for each run, ca. $4 \mathrm{~g}$ of fresh immobilized lipase (Lipozyme $^{\mathrm{TM}}$, from NOVO Nordisk). The packed bed reactor, with a working length of $\mathrm{ca} .12 \mathrm{~cm}$ and an internal diameter of $1 \mathrm{~cm}$, was kept at a constant temperature of either 30 or $40^{\circ} \mathrm{C}$ using an outside thermostated bath. After passing through the packed bed of enzyme, the liquid was recycled to the top of the distillation column using a gear pump. Special care was exercised in controlling the heating power of the mantle and the rotation speed of the pump in order to keep both the vaporization flow rate and the level of liquid at the top of the packed bed at constant values during all experiments. All tubes, connections, and fittings were made of glass or Teflon. Reagent grade acetic acid and ethanol were used as feedstocks. As soon as the first drop of condensate formed at the outlet of the total condenser, both the clock and the gear pump were started and a first sample was taken from the still. Afterwards, sampling was done periodically at approximately every hour for a 9 to 10 -h period. Samples were kept in sealed glass vials at $4^{\circ} \mathrm{C}$ before analysis. The contents of acetic acid, ethanol, and ethyl acetate were determined by HPLC using an autosampler; separation was achieved with an Aminex ${ }^{\mathrm{TM}}$ Ion exclusion column (BIORAD), using $0.0005 \mathrm{M}$ sulphuric acid as eluant at $0.5 \mathrm{~mL} / \mathrm{min}$; and detection was made by measurement of the refractive index. The content of water was determined by Karl-Fisher titration.

\section{Results and discussion}

The evolution of the molar concentrations of the alcohol, acid, ester, and water with time for various initial concentrations and temperatures are depicted in Figures 2 and 3. The molar fractions of these compounds after $9 \mathrm{~h}$ of reaction are listed in Table 1 . The performance of a classical configuration employing a single reactor continuously fed from the batch still under total recycle conditions at both 30 and $40^{\circ} \mathrm{C}$ yielded molar concentrations for the ethyl ester which were negligible in view of the experimental and analytical variability; hence, the experimental data thus obtained were not overlaid in Figures $\mathbf{2}$ and $\mathbf{3}$ for the sake of clearliness. The order of magnitude of the conversions obtained with such classical configuration were in agreement with the mass balances based on the equilibrium constants for both temperatures (see Table 1), which were estimated from the standard Gibb's energies of formation at $298 \mathrm{~K}$ for ethanol, acetic acid, water and ethyl acetate (Smith and van Ness, 1987), their isobaric heat capacities (Perry et al., 1984), and van't Hoff's law (Smith and van Ness, 1987). (In this calculation, the Poyinting correction on the liquid fugacities was neglected as usual; rough calculations from liquid/vapor data available in the literature have indicated that the product of the activity coefficients of the products divided by the product of the activity coefficients of the reactants does not depart very much from unity irrespective of the concentrations utilized in the range of interest; for these facts, the equilibrium constants degenerate onto products of the molar fractions of every component raised to their algebraic stoichiomctric coefficients, and so all reasonings pertaining to the theoretical and actual reaction extents are hereafter based on the molar fractions instead of the activities).

Careful inspection of Figures 2 and 3 indicates that, although the decrease in the concentrations of either acetic acid or ethanol and the increase in the molar concentration of ethyl ester are approximately equal to one another within experimental error, the concentration of water is clearly and consistently above the value predicted by the stoichiometry of the reaction. Therefore, atmospheric water vapor must have been gradually dissolved in the reacting system. Due to this nonreactional source of water, the analyses pertaining to the extent of reaction with respect to equilibrium should to advantage be based on the hypothetical molar fractions if all water was originated as a reaction product, as depicted in Table 1. In this table are also listed values for the conversion of acid and the ratio of the reaction products under the aforementioned conditions and equilibrium conditions. 

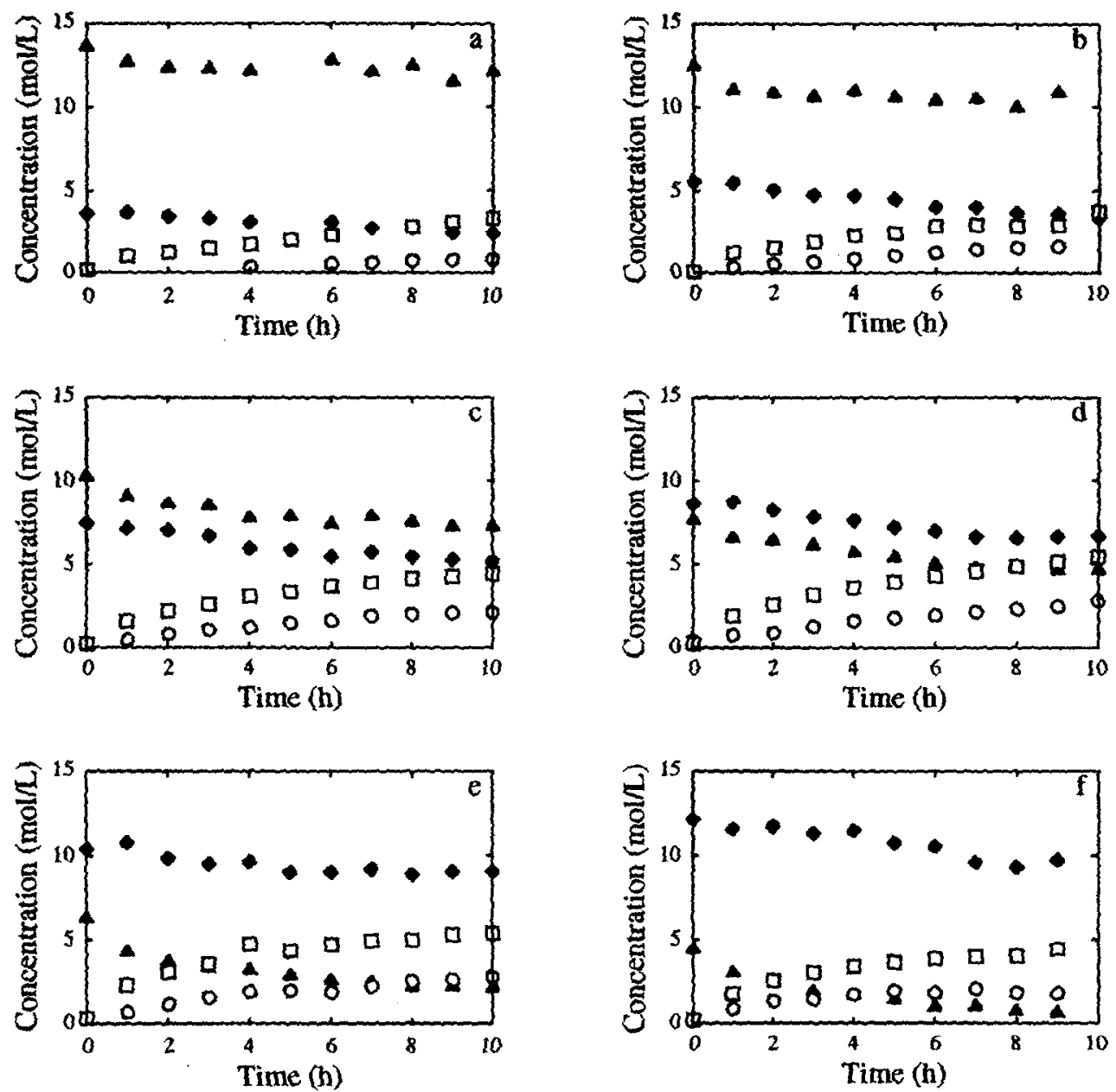

Figure 2: Variation of the concentrations of acetic acid $(\downarrow)$, ethanol $(\Lambda)$, ethyl acetate $(0)$, and water (D) with time of reaction at $30^{\circ} \mathrm{C}$ for initial mole fractions of acid equal to 0.2 (a), 0.3 (b), 0.4 (c), 0.5 (d), $0.6(\mathrm{e})$, and $0.7(\mathrm{f})$.

Inspection of Table 1 indicates that (i) the extents of the corrected conversion of acetic acid range from 0.01 to 0.32 at $30^{\circ} \mathrm{C}$, and from 0.13 to 0.25 at $40^{\circ} \mathrm{C}$, and (ii) they are maximum at ca. 0.3 and 0.7 , respectively, initial mole fractions of acetic acid. Furthermore, the ratio of the corrected reaction product to the equilibrium reaction product increases monotonically from 2 to 32 at $30^{\circ} \mathrm{C}$, and from 5 to 27 at $40^{\circ} \mathrm{C}$ when the initial molar fraction of acid in the feed increases from 0.2 to 0.7 . The former observation probably arises from a compromise between the theoretical fact that conversions are thernodynamically maximal when the reactants are initially at stoichiometric ratios and the experimental fact that conversions increase with increasing molar inventories of acid in the feed. The latter observation is likely due to the fact that acetic acid (one of the reactants) is the least volatile component in the reaction system studied; hence, in tends to concentrate in the lower portion of the distillation column and is thus prevented to reach the reactor located at the top of the distillation column to a shorter extent with higher average concentrations in the batch still. 

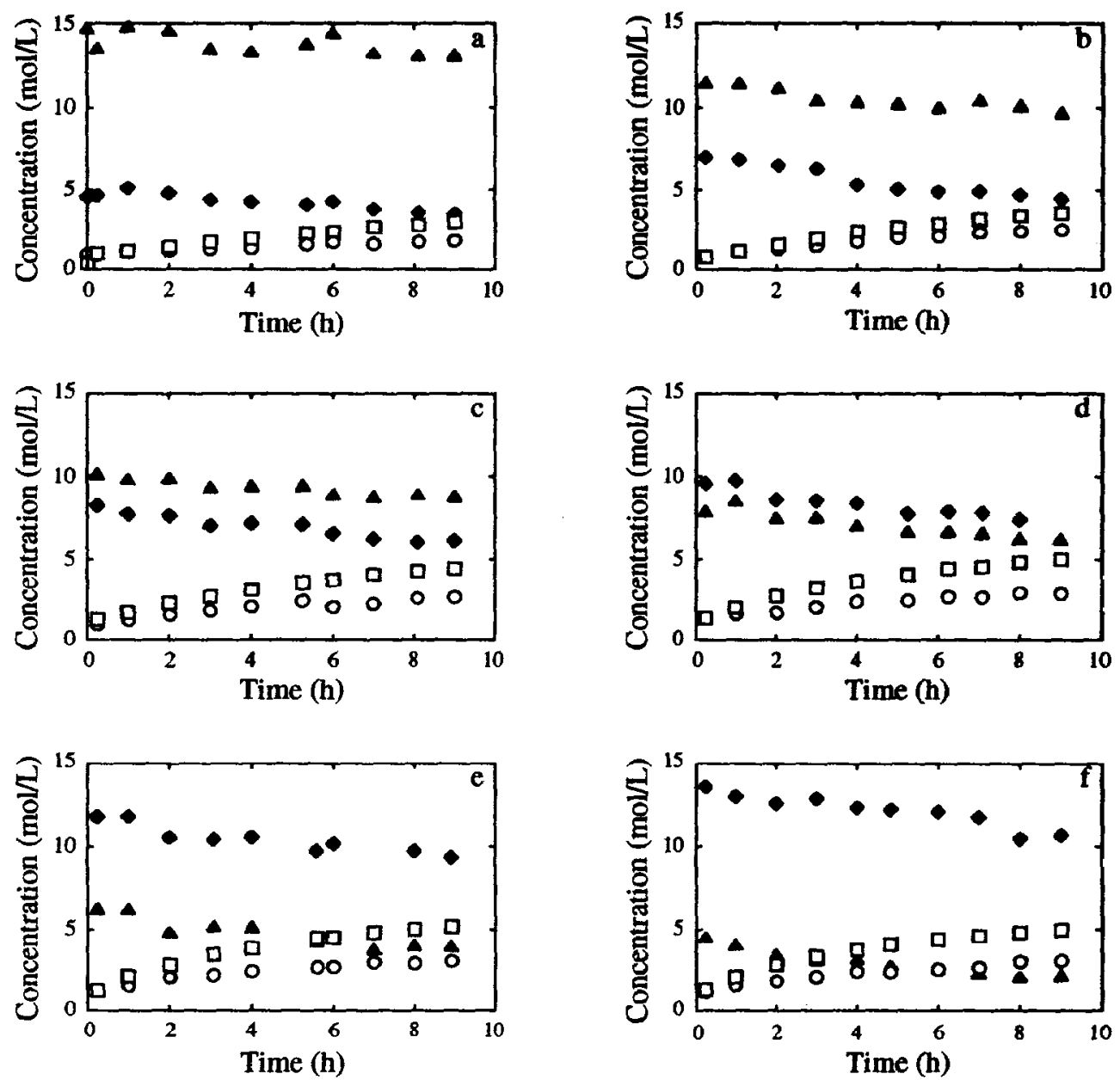

Figure 3: Variation of the concentrations of acetic acid $(\bullet)$, ethanol $(\Delta)$, ethyl acetate $(0)$, and water $(\square)$ with time of reaction at $40^{\circ} \mathrm{C}$ for initial mole fractions of acid equal to $0.2(\mathrm{a}), 0.3(\mathrm{~b}), 0.4(\mathrm{c}), 0.5$ (d), $0.6(\mathrm{e})$, and 0.7 (f).

Performance of the experimental set-up utilized does not require preliminary activation of the immobilized lipase with catalytic water for full ester synthesis activity. In addition, the performance of the combination of the reactor with the distillation column is much better than that of a single reactor operating at 30 or $40^{\circ} \mathrm{C}$ (see Table 1) because the equilibrium constraints of the latter are largely overcome by the former. (Since water is dissolved in a gradual fashion as reaction time elapses, the true reaction enhancement should actually be given as the integral average of the corrected reaction product at every time; this integral average is comprised between the values of $\chi$ listed in the first row and in the second row (*) for every set of experimental conditions in Table 1; therefore, the range discussed above for the corrected reaction products lies on the conservative side). Although this communication describes a novel process combination encompassing enzymes, striking examples of integration of distillation and reaction involving reactions with ethanol as either a reactant or a product have found commercial interest in the past; the former situation pertains to the production of ethyl acetate from ethanol and acetic acid using sulfuric acid as a homogeneous catalyst as described by the U. S. patents $1,454,462$ and $1,454,463$, whereas the latter situation encompasses 
the Alfa-Laval Biostill ${ }^{\mathrm{TM}}$ industrial process for the production of ethanol via fermentation brought about by yeasts.

Table 1: Initial molar fractions of reactants ( $x_{A, 0}$ : acetic acid, and $x_{E, 0}$ : ethanol), molar fractions of reactants and products calculated from the experimental data obtained $9 \mathrm{~h}$ after startup $\left(\mathrm{x}_{\mathrm{A}}\right.$ : acetic acid, $\mathrm{x}_{\mathrm{E}}$ : ethanol, $x_{p}$ : ethyl acetate, and $x_{W}$ : water) and molar fractions of reactants and products obtained after $9 \mathrm{~h}$ of reaction corrected under the assumption that $x_{W}$ should be equal to $x_{p}(*)$, actual reaction product $\left(\chi=\mathrm{XP} \cdot \mathrm{XW}_{\mathrm{W}} / \mathrm{x}_{\mathrm{A}} \cdot \mathrm{x}_{\mathrm{E}}\right)$ and corrected reaction product $(*)$, equilibrium reaction product $\left(\chi_{\mathrm{eq}}\right)$, conversion of acetic acid $\left(Y_{A}=\left(x_{A, 0}-x_{A}\right) / x_{A, 0}\right)$, and ratio of the reaction products $\left(\chi / \chi_{\text {eq }}\right)$ for the two temperatures experimented $\left(\mathrm{T}\right.$ in $\left.{ }^{\circ} \mathrm{C}\right)$.

\begin{tabular}{|c|c|c|c|c|c|c|c|c|c|c|}
\hline $\mathbf{T}$ & $\mathbf{x}_{\mathbf{A}, 0}$ & $\mathbf{X E}_{\mathbf{E}, 0}$ & $\mathbf{x}_{\mathbf{A}}$ & $\mathbf{X E}$ & $\mathbf{X P}$ & $\mathbf{x} \mathbf{W}$ & $\chi$ & $\chi_{\text {eq }}$ & $\mathbf{Y}_{\mathbf{A}}$ & $x^{\prime} \chi_{\text {eq }}$ \\
\hline 30 & 0.200 & 0.800 & $\begin{array}{c}0.136 \\
0.156^{*}\end{array}$ & $\begin{array}{c}0.644 \\
0.740^{*}\end{array}$ & $\begin{array}{c}0.045 \\
0.052^{*}\end{array}$ & $\begin{array}{c}0.175 \\
0.052^{*}\end{array}$ & $\begin{array}{c}0.090 \\
0.023^{*}\end{array}$ & 0.014 & $\begin{array}{c}0.32 \\
0.22^{*}\end{array}$ & $\begin{array}{c}6.43 \\
1.64^{*}\end{array}$ \\
\hline 30 & 0.300 & 0.700 & $\begin{array}{c}0.190 \\
0.204^{*}\end{array}$ & $\begin{array}{c}0.570 \\
0.612^{*}\end{array}$ & $\begin{array}{c}0.086 \\
0.092^{*}\end{array}$ & $\begin{array}{c}0.154 \\
0.092^{*}\end{array}$ & $\begin{array}{c}0.122 \\
0.068 *\end{array}$ & 0.014 & $\begin{array}{c}0.37 \\
0.32^{*}\end{array}$ & $\begin{array}{l}8.71 \\
4.86^{*}\end{array}$ \\
\hline 30 & 0.400 & 0.600 & $\begin{array}{c}0.278 \\
0.314^{*}\end{array}$ & $\begin{array}{c}0.386 \\
0.438 *\end{array}$ & $\begin{array}{c}0.110 \\
0.124^{*}\end{array}$ & $\begin{array}{c}0.226 \\
0.124^{*}\end{array}$ & $\begin{array}{c}0.233 \\
0.112^{*}\end{array}$ & 0.014 & $\begin{array}{c}0.31 \\
0.22^{*}\end{array}$ & $\begin{array}{c}16.6 \\
8.00^{*}\end{array}$ \\
\hline 30 & 0.500 & 0.500 & $\begin{array}{c}0.348 \\
0.405 *\end{array}$ & $\begin{array}{c}0.249 \\
0.289 *\end{array}$ & $\begin{array}{c}0.132 \\
0.153^{*}\end{array}$ & $\begin{array}{c}0.271 \\
0.153^{*}\end{array}$ & $\begin{array}{c}0.411 \\
0.200^{*}\end{array}$ & 0.014 & $\begin{array}{c}0.30 \\
0.19 *\end{array}$ & $\begin{array}{c}29.4 \\
14.3^{*}\end{array}$ \\
\hline 30 & 0.600 & 0.400 & $\begin{array}{c}0.468 \\
0.543^{*}\end{array}$ & $\begin{array}{c}0.121 \\
0.141^{*}\end{array}$ & $\begin{array}{c}0.136 \\
0.158^{*}\end{array}$ & $\begin{array}{c}0.275 \\
0.158^{*}\end{array}$ & $\begin{array}{c}0.660 \\
0.326^{*}\end{array}$ & 0.014 & $\begin{array}{c}0.22 \\
0.10^{*}\end{array}$ & $\begin{array}{c}47.1 \\
23.3^{*}\end{array}$ \\
\hline 30 & 0.700 & 0.300 & $\begin{array}{c}0.582 \\
0.691^{*}\end{array}$ & $\begin{array}{c}0.044 \\
0.053 *\end{array}$ & $\begin{array}{c}0.108 \\
0.128^{*}\end{array}$ & $\begin{array}{c}0.266 \\
0.128^{*}\end{array}$ & $\begin{array}{c}1.126 \\
0.447^{*}\end{array}$ & 0.014 & $\begin{array}{c}0.17 \\
0.01 *\end{array}$ & $\begin{array}{l}80.4 \\
31.9 *\end{array}$ \\
\hline 40 & 0.200 & 0.800 & $\begin{array}{c}0.164 \\
0.174 *\end{array}$ & $\begin{array}{c}0.610 \\
0.648^{*}\end{array}$ & $\begin{array}{c}0.084 \\
0.089 *\end{array}$ & $\begin{array}{c}0.142 \\
0.089^{*}\end{array}$ & $\begin{array}{c}0.119 \\
0.070^{*}\end{array}$ & 0.015 & $\begin{array}{c}0.18 \\
0.13^{*}\end{array}$ & $\begin{array}{c}7.93 \\
4.67^{*}\end{array}$ \\
\hline 40 & 0.300 & 0.700 & $\begin{array}{c}0.221 \\
0.233^{*}\end{array}$ & $\begin{array}{c}0.480 \\
0.507 *\end{array}$ & $\begin{array}{c}0.123 \\
0.130^{*}\end{array}$ & $\begin{array}{c}0.176 \\
0.130^{*}\end{array}$ & $\begin{array}{c}0.204 \\
0.143^{*}\end{array}$ & 0.015 & $\begin{array}{c}0.26 \\
0.22^{*}\end{array}$ & $\begin{array}{l}13.6 \\
9.53^{*}\end{array}$ \\
\hline 40 & 0.400 & 0.600 & $\begin{array}{c}0.278 \\
0.302 *\end{array}$ & $\begin{array}{c}0.400 \\
0.436^{*}\end{array}$ & $\begin{array}{c}0.120 \\
0.131 *\end{array}$ & $\begin{array}{c}0.202 \\
0.131^{*}\end{array}$ & $\begin{array}{c}0.218 \\
0.130^{*}\end{array}$ & 0.015 & $\begin{array}{c}0.31 \\
0.25^{*}\end{array}$ & $\begin{array}{c}14.5 \\
8.67 *\end{array}$ \\
\hline 40 & 0.500 & 0.500 & $\begin{array}{c}0.343 \\
0.380^{*}\end{array}$ & $\begin{array}{c}0.290 \\
0.322^{*}\end{array}$ & $\begin{array}{c}0.134 \\
0.149^{*}\end{array}$ & $\begin{array}{c}0.233 \\
0.149 *\end{array}$ & $\begin{array}{c}0.314 \\
0.181^{*}\end{array}$ & 0.015 & $\begin{array}{c}0.31 \\
0.24^{*}\end{array}$ & $\begin{array}{c}20.9 \\
16.0^{*}\end{array}$ \\
\hline 40 & 0.600 & 0.400 & $\begin{array}{c}0.432 \\
0.479 *\end{array}$ & $\begin{array}{c}0.185 \\
0.205^{*}\end{array}$ & $\begin{array}{c}0.142 \\
0.158^{*}\end{array}$ & $\begin{array}{c}0.241 \\
0.158^{*}\end{array}$ & $\begin{array}{c}0.428 \\
0.254^{*}\end{array}$ & 0.015 & $\begin{array}{c}0.28 \\
0.20^{*}\end{array}$ & $\begin{array}{c}28.5 \\
16.9 *\end{array}$ \\
\hline 40 & 0.700 & 0.300 & $\begin{array}{c}0.511 \\
0.562 *\end{array}$ & $\begin{array}{c}0.104 \\
0.114^{*}\end{array}$ & $\begin{array}{c}0.147 \\
0.162^{*}\end{array}$ & $\begin{array}{c}0.238 \\
0.162^{*}\end{array}$ & $\begin{array}{c}0.658 \\
0.410^{*}\end{array}$ & 0.015 & $\begin{array}{c}0.27 \\
0.20 * \\
\end{array}$ & $\begin{array}{c}43.9 \\
27.3^{*}\end{array}$ \\
\hline
\end{tabular}

\section{Acknowledgements}

Partial funding for the research work described above was provided by the Portuguese Board for Scientific and Technological Research (JNICT-Portugal) through Programa Base de Investigação Científica e Tecnológica - 1993 (Process Integration - Extractive Biocatalysis) and Programa CIENCIA (BD/2081/92-IF).

\section{References}

Chulalaksananukul, W., Condoret, J. S., Delorme, P., and Willemot, R. M. (1990). FEBS Lett. 276, 181-184. Dias, S. F., Vilas-Boas, L., Cabral, J. M. S., and Fonseca, M. M. R. (1991). Biocatalysis 5, 21-34.

Khurana, A. L. and Ho, C. T. (1990). J. Liq. Chromat. 13, 715-725.

Knez, Z., Leitgeb, M., Zavrsnik, D., and Lavric, B. (1990). Fat Sci. Technol . 92, 169-172.

Langrand, G., Rondot, N., Triantaphylides, C., and Baratti, J. (1990). Biotechnol. Lett. 12, 581-586.

Manjón, A., Iborra, J. L., and Arocas, A. (1991). Biotechnol. Lett. 13, 339-344.

Norin, M., Boutelje, J., Holmberg, E., and Hult, K. (1988). Appl. Microbiol. Biotechnol. 28, 527-530.

Perry, R. H., Green, D. W., and Maloncy, J. O. (Eds.) (1984). Perry's Chemical Engineers' Handbook, New York: McGraw-Hill.

Smith, J. M., and van Ness, H. C. (1987). Introduction to Chemical Engineering Thermodynamics, New York: McGraw-Hill.

Welsh, F. W., Williams, R. E., and Dawson, K. H. (1990). J. Food Sci. 55, 1679-1682. 